\title{
FINANCIAL AND ACCOUNTING ASPECTS OF THE ACTIVITY OF BULGARIAN AGRICULTURAL ENTERPRISES
}

\author{
N. Penev*, J. Andreev \\ Trakia University, Stara Zagora, Bulgaria
}

\begin{abstract}
The Bulgarian economy is part of the global economic system. The foregoing leads to the diffusion of capital, products, innovation, ideas, partnerships. The Bulgarian agricultural sector is the basis of the country's economic development. Enterprise management in the sector is set to diverse challenges. Effective management is associated with the entity's accounting and financial system. This study examines the current state and prospects of the business management of the agricultural sector in Bulgaria.
\end{abstract}

Key words: Finance, Accounting, Agricultural business, Management, Ecology

\section{INTRODUCTION}

The Bulgarian economy is part of the global economic system. The foregoing leads to the diffusion of capital, products, innovation, ideas, partnerships. The Bulgarian agricultural sector is the basis of the country's economic development. Enterprise management in the sector is set to diverse challenges. Effective management is associated with the entity's accounting and financial system. This study examines the current state and prospects of the business management of the agricultural sector in Bulgaria. Accountancy of each industry is characterized by its special features. As it is typical for the science, the accounting has changed and reached an evolution in theoretical and methodological aspect. In recent years accounting has improved quite logically in public sector, banking, agriculture and industry (1). Evolvement of accountancy in these spheres is as a result of the changes of the socio - economical life of our country.

$$
* * *
$$

The aim of the presented study is to describe contemporary financial and accounting aspects of the activity of bulgarian agricultural enterprises.

Effective management of agricultural enterprises is impossible without accounting

\footnotetext{
*Correspondence to: Assos. prof. Nikolay Penev, PhD; Trakia University, Faculty of Economics, Stara Zagora, Bulgaria; e-mail: penevbg@abv.bg ; www.uni-sz.bg
}

and economical information, which is created, processes and systemized thanks to the accounting system. Thanks to the financial report of the company, (based on the accounting information) could be received information for the overall business activity of the agricultural companies. Main tasks, facing accounting could be described in this way: 1) providing information, necessary for the provision of short-and long term plans and forecast of the agricultural enterprises, as well as exercising current control on their implementation; 2) providing information for system and timely control over protection of property; 3) providing information for conduction of thorough economical analysis of the business activity with the aim of finding reserves in order to increase its effectiveness; 4) providing information about contract implementation with partners, about quality of products delivered to costumers, for the timely payment with the customers, suppliers and others.

The final phase of the accounting process is connected with formulation and release of the financial report. It includes balance sheet, the income statement of the company, equity report, cash flow statement, accounting policy and the explanations to the report.

Users of the accounting report information could be - shareholders, investors, creditors, national institutions, customers, personnel, suppliers and others. Given the accuracy in the preparation of reports, there might be negative 
consequences when mistakes are made, which could be due to unqualified staff members, or to random errors in the calculations and computer programs or deliberately provided false information. The last one could reflect the company by changing the real perception of the state of the company, as well as misleading of control and tax authorities, defrauding customers, contractors and the country. Control authorities could be from national institutions - central and local, as well as sector and other authorities, under which supervision is the particular company. For this reason is conducted internal and external audit. For mistakes, depending on type and size, sanctions of different scale are provided.

Regulations in the agrarian sector are associated with a number of laws and regulations that may be specific and general. The general regulate the whole economic and financial activity of the companies, while the specific ones refer to the particular accounting. To the common regulations are added laws, concerning the activity of the business as far as civil, commercial, contractual, tax etc. right is concerned (2). In the group of the specific regulations are Accounting Law, International Accounting Standards, National Standards for financial reports for small and middle range companies, Book-keeping of the company.

In Accounting Law is settled the methodology of developing and functioning of the accounting systems, as well as preparation of accounting reports, which describe in a reliable way the property and the financial situation of the company and changes that have occurred, together with realized financial results.

$* * *$

Companies in the agrarian sector conduct accounting recording in chronological order, and the accounting is being carried out regarding the following principles, common for the accountancy: 1) working company; 2) current charging; 3) comparison between income and expenditure; 4) advantage of the content over form; 5) accurate and fair performance; 6) materiality; 7) cautiousness; 8) historical value; 10) valuable relation between beginning and end balance; 11) documentary validity; 12) possible retention of accounting policy.

Applicable accounting standards in the Republic of Bulgaria are approved by Council of Ministers Decree and their implementation is obligatory for the companies operating on the territory of the country, including the sector of the agrarian sector.
Each company has the possibility to accept a book-keeping plan, and following it to conduct its activity. In the plan are included accounts in the following sections: capital, long term assets, inventories, plans, funds, expenses, revenues, balance accounts. Accounts are arranged in sections and groups, using the decimal system for encoding sections, groups, and accounts. Companies develop their individual book-keeping plan, taking into account the specific structures, activities and the accepted by the company organization of accounting. In last decade is observed some "liberalization" of accounting process of the country, and to the individual companies is given significant freedom in the process of organizing the accounting.

Main characteristic of the accounting process is a compilation of a large volume of documentation. Accounting document is a written record of information for conducted business operations. Accounting documents could be classified according to different criteria (3). According to the place of compilation they could be internal and external. External documents are compiled by other companies and come to the company's accounting from outside. Responsible for the accuracy of the information is the person who prepared the document. The one, taking the documents should check the described business activity. Such documents are an invoice for bought goods and services, payment and banking documents and others.

Internal documents, are those issued by the company - cash, warehousing, production and other documents. According to accounting law reliability for information in accounting documents and in their informational carriers are responsible the authorities who have compiled them and signed them. Persons who have ordered the execution of business operations, are responsible for their legality and appropriateness (4). It is necessary to differentiate the responsibility of the ones, who have a particular operation done, from responsibility of employees from the accounting, who only transform these orders in accounting documents. Responsibility for accounting in agrarian industry is given to the chief accountant.

Depending on the character of information, which they carry documents might be divided into: primary, secondary and records. Primary document has information about a first recorded business operation. Secondary documents carry summarized information, received by the primary ones. The record keeps 
PENEV N., et al.

chronologically systemized information for business operations from primary and secondary accounting documents (5). Accounting records are special types of secondary documents, which contain summarized information, already mentioned in both primary and secondary accounting documents. Accounting records are the books for income and expenditures, inventory ledger, book inventories, cash book and others.

$* * *$

Documentation process is the way of movement of the accounting documents from the moment of their compilation or when they are received in the enterprise till the moment when they are submitted in the permanent accounting archive for storage.

Contemporary economic conditions in the agrarian sector and bulgarian industry require evolvement of systems of processing and storage of accounting information (6). Security of information raises problems of a particular type. In the development of automatic processing of accounting information in the agrarian sector, is ensured integrity of performance of indexes and requisites, used in accountancy for individual sites, as well as organization of informational relations of each site with the other ones. In processing accounting information in agrarian sector, it is classified and encoded, by providing full coverage of all the classification objects; with a possibility to include new classification groups and objects; automatically are received all accounting indexes separately or grouped according to different feature; commonly used specifications and encoding systems.

Book-keeping plan of the agrarian company is a basis for classification in computer processing of accounting information, and documentary gathering of business operations is carried out following the regulations of the accounting law and law for accounting standards. Information from primary and other accounting documents form informational basis, needed for the functioning of the accounting system in the agrarian organization. Main role in accounting of organizations of agrarian industry plays the chief accountant. He defines the form of the accounting. Form of accounting ensures preliminary current control over the primary accounting information from implementation of agrarian activity; synchronized implementation of chronological and systematical /analytical, synthetically/ accountancy; openness of the system of accounting in order to achieve additional management tasks; logical transformation of accounting information in its processing and usage; presenting necessary accounting information for motivated management decisions, for taxation and the protection of property, which in agrarian sector is specific.

Main characteristics of accounting information in agrarian sector do not differentiate compared to other industries. Objectivity, accuracy, completeness, reliability, availability, and timeliness of accounting information are important for its users. Effective management of agrarian organization is not possible without accounting, and accounting knowledge of managers is obligatory.

$* * *$

Next highlight of the study, is related to the contemporary problems facing accountancy of agrarian sector and it is the problem of financial and tax control over the activity of the sector. Creating statistical information and realization of business analysis in the sector is in direct relation with the effectiveness of the management. Management personnel and human factor in agrarian sector have unique significance. The reason behind this is the specific business. Motivation of staff, wages, relations with them are interrelated.

When describing contemporary theoreticallymethodological problems facing accountancy of organizations in agrarian sector is necessary to pay attention to accounting. In preparation of sample book-keeping plan of agrarian enterprise are followed the main rules, common for the accounting of other sectors in the industry. Sections of book-keeping plan of agrarian enterprise are the following: accounts for capital; accounts for long term assets; accounts for short term assets (inventories, production, goods etc.); accounts on claims and liabilities of the company; financial accounts; accounts of expenditure; accounts for revenue, accounts for contingent assets and liabilities. The use of codes is specific for accounting, and it supports and facilitates the work of the chief accountant.

Presented problems of the study, describe challenges facing not only accountancy in the agrarian sector of Bulgaria but also of the management of the system. The national institutions occupied with the problems of the sector, non-government organizations, associations, and most of all enterprises from this industry should take into consideration the international trends of economic development. Climate change directly affect agriculture and in long term plan will lead to a decrease of the 
revenue. This will reflect on problems related to innovations and investments in the sector and in the next years this will only lead to more problems. They could even become more severe because of the geographical position of Bulgaria and the geopolitical and economical interests of the region.

Accountancy is part of the management system of the agrarian companies. The systematical approach in the business activity in agriculture, requires accounting to be adaptive with fast pace to the new realities, and the accountants themselves to have complex economical knowledge. Nowadays more than ever, in the management of each company of the agrarian industry, is required knowledge, skills, flexibility. Only in this way there will be effective counteraction of the crisis situations and sustainability of the development of agrarian sector in Bulgaria will be ensured.

\section{REFERENCES}

1. Kabaivanov, Stanimir. 2012. Risk Modeling with Monte Carlo and Real Option Analysis. Report of the International Scientific Conference "Research Methods and Technologies in Economic and Social Sciences", Plovdiv, 2012, Faculty of Economics, Plovdiv University "Paisiy Hilendarski", Plovdiv, Bulgaria, 6-7 November, 421 - 426, 2012, ISBN: 978954-423-837-7.

\section{PENEV N., et al.}

2. Penev, N. 2008b. "Problems in Applying Conceptual Frame of Bank Account Policy" in Problems in Accounting in Bulgaria and Russia, edited by V. Merazchiev, G. Batashki et al., AI Tzenov Svistov 3.1.8, 202-207, 2008.

3. Tavella, Domingo. 2002. Quantitative Methods in Computational Finance. New York: John Wiley \& Sons.

4. Milev, Mariyan, Georgieva, Svetla and Markovska, Veneta. 2013. Valuation of Exotic Options in The Framework of Levy Processes. 39 th International Conference "Application of Mathematics in Engineering and Economics", organized by the Faculty of Applied Mathematics and Informatics, Technical University of Sofia, 8 - 13 June, 2013.

5. Iskra Nencheva. Situation and prospects of customs policy in Bulgaria. Trakia Journal of Sciences, Vol. 11, Suppl. 1, 2013.

6. Mariyan, Milev, Petkova, Milena and Lambova, Antonia. Monte Carlo Method for Pricing Financial Derivatives, Report of the International Scientific Conference "Research Methods and Technologies in Economic and Social Sciences", Plovdiv, 2012, (Proceedings of the International Conference 'Research Methods and Techniques in Economics and Social Sciences "), Faculty of Economics, Plovdiv University, Paisiy Hilendarski, Plovdiv, Bulgaria, 6-7 November, 2012. 328-337, 2012, ISBN: 978-954-423-837-7. 